\title{
Effect of Levosimendan and Nigella Sativa on Erythrocyte Deformability During Myocardial Ischaemia-Reperfusion Injury in Rats
}

\author{
Ratlarda Miyokardiyal İskemi-Reperfüzyon Hasarı Sırasında Levosimendan ve Nigella Sativa'nın Eritrosit \\ Deformabilitesine Etkisi
}

\author{
Abdullah Özer ${ }^{1}$, Faruk Metin Comu², Ayşegül Küçük ${ }^{3}$, Yiğit Kılıç4, Barış Mardin ${ }^{1}$, Metin Alkan ${ }^{5}$, Levent Oktar ${ }^{1}$, Mustafa Arslan ${ }^{5}$ \\ Yusuf Ünal ${ }^{5}$
}

\author{
${ }^{1}$ Department of Cardiovascular Surgery, Gazi University Faculty of Medicine, Ankara, Turkey \\ ${ }^{2}$ Department of Physiology, Kirikkale University Faculty of Medicine, Kirikkale, Turkey \\ ${ }^{3}$ Department of Physiology, Dumlupinar University Faculty of Medicine, Kutahya, Turkey \\ ${ }^{4}$ Dr. Siyami Ersek Cardiovascular and Thoracic Surgery Training and Research Hospital, Pediatric Cardiovascular Surgery Clinic, Haydarpasa, Istanbul, Turkey \\ ${ }^{5}$ Department of Anaesthesiology and Reanimation, Gazi University Faculty of Medicine, Ankara, Turkey
}

\section{ABSTRACT}

Objective: Ischaemia-reperfusion (IR) injury is a chain of events put in place by tissue ischaemia. Reperfusion following the cellular damage causes an active inflammatory response. Erythrocyte deformability and plasma viscosity play a critical role in tissue and organ perfusion. In this study we aimed to evaluate the effect of levosimendan and nigella sativa on erythrocyte deformability during myocardial IR injury in rats.

Methods: Twenty-four Wistar albino rats were included in the study. The animals were randomly divided into four experimental groups. The coronary arteries of rats in Group C (control group) were not occluded or reperfused. Myocardial IR was performed by ligating the left anterior descending coronary artery for 30 min, followed by $2 \mathrm{~h}$ of reperfusion in the IR (IR), IR-levosimendan $(24 \mu \mathrm{g} / \mathrm{kg})(\mathrm{IRL})$ group and IR-nigella sativa $(0.2 \mathrm{~mL} / \mathrm{kg}$ ) (IRNS) group. Erythrocyte suspensions formed with a PBS buffer solution containing $5 \%$ htc were used to measure the deformability.

Results: As a result compared to control group, IR increased the relative resistance, a marker of erythrocyte deformability, significantly $(p<0.05)$. There were significant differences between the groups according to the comparisons with ANOVA test $(p<0.0001)$. The results obtained after corrections with Bonferroni test were as follows: Comparisons of the IRL and IRNS groups revealed similar results $(p=0.764)$. The values of the IR group were significantly higher than those of the control, IRNS and IRL groups $(p<0.0001, p=0.001$, $\mathrm{p}=0.003$, respectively).

Conclusion: Rats with IR injury had decreased erythrocyte deformability. This injury might cause more problems in microcirculation. Levosimendan and nigella sativa may be useful in reducing the adverse effects of this type of injury.

Key Words: Erythrocyte deformability, myocardial ischaemia-reperfusion, nigella sativa, levosimendan, rat

Received: 12.16 .2017
Accepted: 01.07.2018

\section{ÖZET}

Amaç: İskemi-reperfüzyon (IR) hasarı, doku iskemisi sonucu gerçekleşen bir olaylar zinciridir. Hücresel hasarı takiben reperfüzyon, aktif bir inflamatuar yanıta neden olur. Eritrosit deformabilitesi ve plazma viskozitesi doku ve organ perfüzyonunda kritik bir rol oynar. Bu çalışmada, ratlarda miyokardiyal íR hasarı sırasında levosimendan ve nigella sativa'nın eritrosit deformabilitesi üzerine etkisini araştırmayı amaçladık.

Yöntem: Yirmi dört adet Wistar albino rat çalışmaya dahil edildi. Hayvanlar rastgele dört deney grubuna ayrıldı. Grup K'daki (kontrol grubu) ratların koroner arterlerine oklüzyon veya reperfüzyon yapılmadı. Miyokardiyal IR, sol ön inen koroner arterin 30 dakika süreyle bağlanması, ardından IR (IR), İR-levosimendan (24 $\mathrm{\mu g} / \mathrm{kg}$ ) (iRL) ve IR-nigella sativa $(0.2 \mathrm{~mL} / \mathrm{kg}$ ) (IRNS) gruplarında 2 saat reperfüzyon ile gerçekleştirildi. Deformabiliteyi ölçmek için\% 5 htc içeren bir PBS tampon çözeltisi ile oluşturulan eritrosit süspansiyonları kullanıldı.

Bulgular: Sonuç olarak, kontrol grubuna kıyasla IR, eritrosit deformabilitesinin bir belirteci olan nispi direnci artırdı $(p<0.05)$. Gruplar arasında ANOVA testi ile yapılan karşılaştırmalara göre anlamlı fark vardı $(p<0.0001)$. Bonferroni testi ile yapılan düzeltmelerden sonra elde edilen sonuçlar şu şekildedir: IRL ve IRNS gruplarının karşılaştırmaları benzer sonuçlar vermiştir $(p=0.764)$. iR grubunun değerleri kontrol, İRNS ve İRL gruplarından anlamlı derecede yüksekti (sırasıyla $p<0.0001, p=0.001, p=0.003$ ).

Sonuç: İskemi reperfüzyon hasarı olan ratlarda eritrosit deformabilitesi azaldı. Bu yaralanma mikrodolaşımda daha fazla sorun yaratabilir. Levosimendan ve nigella sativa, bu tip yaralanmaların olumsuz etkilerini azaltmada yararlı olabilir.

Anahtar Sözcükler: Eritrosit deformabilitesi, miyokardiyal iskemi-reperfüzyon, nigella sativa, levosimendan, rat

Geliş Tarihi: 16.12 .2017

Kabul Tarihi: 07.01.2018 


\section{INTRODUCTION}

Cardiac surgery with cardiopulmonary bypass inevitably causes a systemic inflammatory response and ischaemia-reperfusion (IR) injury, which affects multiple organs $(1,2)$. Many tissues and cells can be damaged by free radicals, with red blood cells (RBCs) being one of the most susceptible. During IR, the increased oxidative stress can cause augmented RBC membrane lipid peroxidation, with consequent alteration of cellular deformability. RBC deformability and aggregation have a very important effect on the microcirculation. In the capillaries, where the RBCs must deform to enter and transit vessels smaller than the resting cell diameter, erythrocyte deformability is a crucial factor affecting the flow of blood (3-5).

Levosimendan is a relatively new inotropic and vasodilator agent used in the management of acute and chronic heart failure (6). Its positive inotropic effect is mediated by calcium sensitization of contractile proteins, and its vasodilatory and anti-ischaemic effects are mediated by the opening of adenosine triphosphate-sensitive potassium channels in vascular smooth muscle cells (6-9). The protective effects of levosimendan are not limited to cardiac tissue. Some studies have suggested that levosimendan also attenuates IR injury in the spinal cord, lung and renal tissue (10-12).

Thymoquinone is one of these compounds. It is the main active ingredient of Nigella sativa, commonly known as black cumin or black seed, an annual flowering plant native to some areas such the Mediterranean countries (13). Since its first extraction in 1963 (14), thymoquinone has been shown to act as a potent free radical and superoxide scavenger (15-17). Some studies have suggested that NS also attenuates IR injury in the spinal cord, heart and renal tissue (18-20)

The effects of levosimendan and nigella sativa on myocardial injury induced by left anterior descending (LAD) IR have not yet been investigated. The primary aim of this study was to investigate deformability changes and the role of levosimendan and nigella sativa in preventing these changes in the erythrocytes of rats in an experimental model of myocardial IR injury.

\section{MATERIALS AND METHODS}

\section{Animals and Experimental Protocol}

This study was conducted in the GUDAM Laboratory of Gazi University with the consent of the Experimental Animals Ethics Committee of Gazi University. All the procedures were performed according to the accepted standards of the Guide for the Care and Use of Laboratory Animals. In the study, 24 male Wistar albino rats weighing between 250 and $300 \mathrm{~g}$, raised under the same environmental conditions, were used. For at least one week prior to surgery, the animals were housed in standard cages in a pathogen-free environment, with free access to food (until $2 \mathrm{~h}$ before the anaesthetic procedure) and water and with a $12 \mathrm{~h}$ light/dark cycle. The animals were randomly separated into four groups, each containing six rats.

The rats were anesthetized with an IP injection of $100 \mathrm{mg} / \mathrm{kg}$ of ketamine. The trachea was cannulated for artificial respiration. The chest was shaved, and each animal was fixed in a supine position on the operating table. The chest was opened by a left thoracotomy, followed by sectioning the fourth and fifth ribs about $2 \mathrm{~mm}$ to the left of the sternum. Positive-pressure artificial respiration was started immediately with room air, using a volume of $1.5 \mathrm{ml} / 100 \mathrm{~g}$ body weight at a rate of 60 strokes $/ \mathrm{min}$. Sodium heparin $(500 \mathrm{IU} / \mathrm{kg})$ was administered through the peripheral vein in the tail. After the pericardium was incised, the heart was exteriorized with gentle pressure on the right side of the rib cage. An $8 / 0$ silk suture attached to a $10 \mathrm{~mm}$ micropoint reverse-cutting needle was quickly placed under the left main coronary artery. The heart was then carefully replaced in the chest, and the animal was allowed to recover for $20 \mathrm{~min}$. Anaesthesia was maintained by repetitive injections of $20 \mathrm{mg} / \mathrm{kg}$ ketamine if a positive reaction to surgical stress or intermittent tail pinch could be observed.

There were four experimental groups: Group C (control; $n=6$ ), Group IR (IR; $n=6$ ), Group IRNS (IR-nigella sativa; $n=6$ ) and Group IRL (IR-levosimendan; $n=6$ ). The IRL group underwent left thoracotomy and received IP levosimendan (Simdax $2.5 \mu \mathrm{g} / \mathrm{ml}$, Abbott ${ }^{\circ}$, Orion Pharma, Espoo, Finland) $24 \mu \mathrm{g} / \mathrm{kg}$ diluted in 10 $\mathrm{ml}$ of $0.5 \%$ dextrose administered intraperitoneally $30 \mathrm{~min}$ before ligating the LAD. The IRNS group underwent left thoracotomy and received IP nigella sativa (Tymoquinone 1G, Sigma Aldrich ${ }^{\circ}$ ) $0.2 \mathrm{ml} / \mathrm{kg}$ administered intraperitoneally 30 min before ligating the LAD. A small plastic snare was threaded through the ligature and placed in contact with the heart. The artery was then occluded by applying tension to the ligature ( $30 \mathrm{~min}$ ), and reperfusion was achieved by releasing the tension (120 $\mathrm{min}$ ). However, after the above procedure, the coronary artery was not occluded or reperfused in the control rats.
Intracardiac blood samples were obtained from all the rats. Heparinized total blood samples were used to prepare erythrocyte packs. Deformability measurements were performed using erythrocyte suspensions with 5\% haematocrit $(\mathrm{Htc})$ in a phosphate-buffered saline (PBS) buffer.

Deformability Measurements

Blood samples were carefully taken, and the measurement process was as fast as possible to avoid haemolysis of the erythrocytes. The collected blood was centrifuged at $1000 \mathrm{rpm}$ for $10 \mathrm{~min}$. Serum was removed, in addition to the buffy coat on the erythrocytes. An isotonic PBS buffer was added to the collapsing erythrocytes, and this was centrifuged at $1000 \mathrm{rpm}$ for $10 \mathrm{~min}$. The liquid on the upper surface was removed. Finally, pure red cell packs were obtained from the washing process, which was repeated three times. The erythrocyte packs were mixed with the PBS buffer to generate a suspension with a value of $5 \% \mathrm{Htc}$. These erythrocyte suspensions were used for the measurement of deformability. The collection and the deformability measurements of the erythrocytes were performed at $22^{\circ} \mathrm{C}$.

A constant-current filtrometer system was used in the measurement of the erythrocyte deformability. Samples to be measured were prepared with $10 \mathrm{ml}$ of erythrocyte suspension and PBS buffer. The flow rate was held constant at 1.5 $\mathrm{ml} / \mathrm{min}$ with an infusion pump. A $28 \mathrm{~mm}$ nucleoporin polycarbonate filter with a $5 \mu \mathrm{m}$ pore diameter was preferred. Pressure changes while the erythrocytes passed through the filter were detected by a pressure transducer, and the data were transferred to the computer with the help of an MP30 data equation system (Biopac Systems Inc., Commat, USA). The calculations were performed with related computer programs by measuring the pressure changes at various times. Pressure calibration of the system was performed before each sample measurement. The buffer $\left(P_{T}\right)$ and the erythrocytes $\left(P_{E}\right)$ were passed through the filtration system, and the changes in pressure were measured. The relative refractory period value (Rrel) was calculated by relating the pressure value of the erythrocyte suspension to the pressure value of the buffer. An increasing Rrel in the deformability index was interpreted as adversely affecting the deformability of the erythrocytes. Statistical Analysis

The Statistical Package for the Social Sciences (SPSS, Chicago, IL, USA) 12.0 program was used for the statistical analysis. Erythrocyte deformability between the study groups were assessed using the ANOVA test. The Bonferroni-adjusted test was used if the results of the ANOVA test were significant to determine which groups differed from the others. The results were expressed as mean \pm standard deviation (mean \pm SD). Statistical significance was set at a $p$ value of $<0.05$.

\section{RESULTS}

The results of the study indicated that IR significantly increased the relative resistance, a marker of erythrocyte deformability when compared to control group ( $p<0.05)$, (Figure 1 ). There were significant differences between the groups according to the comparisons with ANOVA test $(p<0.0001)$. The results obtained after corrections with Bonferroni test were as follows: Comparisons of the IRL and IRNS groups revealed similar results $(p=0.764)$. The values of the IR group were significantly higher than those of the control, IRNS and IRL groups $(p<0.0001, p=0.001, p=0.003$, respectively).

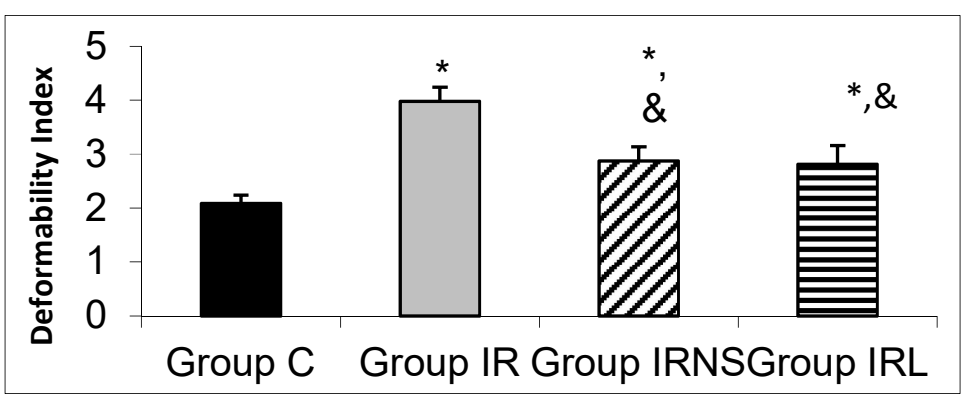

Figure 1: Erythrocyte deformability values of the groups. Each bar represents the mean $\pm S D$.

* $p<0.05$ compared to Group C; \&p< 0.05 compared to Group IR 


\section{DISCUSSION}

The effects of levosimendan on haemodynamics that include increased contractility, improved ejection fraction, increased cardiac output, reduced cardiac filling pressures and reduced systemic, pulmonary and coronary vascular resistance are based on its positive inotropic, lusitropic and vasodilatatory properties $(7,21,22)$. Levosimendan is a calcium sensitizer that increases the sensitivity of the myocardium to calcium, thereby increasing myocardial contractility without a rise in intracellular calcium (23). In addition, levosimendan causes adenosine triphosphate-sensitive potassium channels to open in vascular smooth muscle, resulting in smooth muscle relaxation $(23,24)$. This contributes to vasodilatation and probably anti-ischaemic effects $(22,23)$.

For migration of oxygen and vital molecules to the final organ capillaries and clearance of metabolic wastes, erythrocytes must be able to extend and curve and have the capability to move in these areas. This capacity, called 'deformability', is important in the microcirculation. Altered erythrocyte deformability not only changes the oxygen delivery capacity of the erythrocytes but also the survival of the circulating erythrocytes $(25,26)$.

The administration of levosimendan is also associated with peripheral vasodilation, anti-ischaemic cardioprotection (27), neuroprotection (28) and anti-inflammatory and anti-apoptotic effects (29). We have determined that levosimendan has protective effects on the alteration of eryhtrocyte deformability during myocardial IR injury in rats (30). The black seed oil and tymoquinone by intraperitonial injection were found to shown protective effects on lipid peroxidation process during IR injury in rat hippocampus (31). Previous studies clearly showed that chronic treatment with NS fixed oil effectively influenced blood homeostasis in rats and seemed to induce transient changes in coagulation activity $(32,33)$.

In this study, for the first time to our knowledge, we have reported that IR of the rat myocardium results in significant negative changes that can be observed in erythrocyte deformability and that levosimendan and nigella sativa, administered at the beginning of myocardial ischaemia, can provide varying degrees of protection against negative effects of variations in erythrocyte deformability.

In conclusion, the results of this study clearly demonstrated that erythrocyte deformability is significantly altered in experimental myocardial IR injury in the rat. This might lead to further problems in microcirculation. Thus, measurement of erythrocyte deformability might have an important impact on the follow-up for IR injury. Additionally, levosimendan and nigella sativa administered before the induction of ischaemia had protective effects on these alterations in myocardial IR injury. Other aspects of these findings, including clinical significance and practical applications, merit further experimental and clinical investigation.

\section{Conflict of interest}

No conflict of interest was declared by the authors.

\section{REFERENCES}

1. Robertshaw HJ, Hall GM. Diabetes mellitus: anaesthetic management. Anaesthesia 2006;61:1187-90.

2. McAnulty GR, Robertshaw HJ, Hall GM. Anaesthetic management of patients with diabetes mellitus. Br J Anesth 2000;85:80-90.

3. Peto K, Nemeth N, Brath E, Takacs IE, Baskurt OK, Meiselman HJ, et al. The effects of renal ischemia-reperfusion on hemorheological factors: preventive role of allopurinol. Clin Hemorheol Microcirc 2007;37:347-58.

4. Baskurt OK, Meiselman HJ. Blood rheology and hemodynamics. Semin Thromb Hemostas 2003;29:435-50

5. Brath E, Nemeth N, Kiss F, Sajtos E, Hever T, Matyas L, et al. Changes of local and systemic hemorheological properties in intestinal ischemia-reperfusion injury in the rat model. Microsurgery 2010;30:321-6.

6. Rognoni A, Lupi A, Lazzero M, Bongo AS, Rognoni G. Levosimendan: from basic science to clinical trials. Recent Pat Cardiovasc Drug Discov 2011;6:9-15.

7. Toller WG, Stranz C. Levosimendan, a new inotropic and vasodilatory agent. Anesthesiology 2006;104:556-69.

8. Erdei N, Papp Z, Pollesello P, Edes I, Bagi Z. The levosimendan metabolite OR1986 elicits vasodilation by activating the K(ATP) and $\mathrm{BK}(\mathrm{Ca})$ channels in rat isolated arterioles. Br J Pharmacol 2006;148:696-702.
9. Kaheinen $\mathrm{P}$, Pollesello $\mathrm{P}$, Levijoki J, Haikala $\mathrm{H}$. Levosimendan increases diastolic coronary flow in isolated guinea pig heart by opening ATP-sensitive potassium channels. J Cardiovasc Pharmacol 2001;37:367-74

10. Katircioglu SF, Seren M, Parlar Al, Turan NN, Manavbasi Y, Aydog G, et al Levosimendan effect on spinal cord ischemia-reperfusion injury following aortic clamping. J Card Surg 2008;23:44-8.

11. Yasa H, Yakut N, Emrecan B, Ergunes K, Ortac R, Karahan N, et al. Protective effects of levosimendan and iloprost on lung injury induced by limb ischemiareperfusion: A rabbit model. J Surg Res 2008;147:138-42.

12. Yakut N, Yasa H, Bahriye Lafci B, Ortac R, Tulukoglu e, Aksun M, et al. The influence of levosimendan and iloprost on renal ischemia-reperfusion: An experimental study. Interact Cardiovasc Thorac Surg 2008;7:235-9.

13. Gali-Muhtasib H, Roessner A, Schneider-Stock R. Thymoquinone: a promising anti-cancer drug from natural sources. Int J Biochem Cell Biol 2006;38:1249-53.

14. El-Dakhakhny M. Studies on the chemical constitution of Egyptian N. sativa L. seeds. Planta Med 1963;11:465-70.

15. Awad AS, Kamel R, Sherief MA. Effect of thymoquinone on hepatorena dysfunction and alteration of CYP3A1 and spermidine/spermine N-1-acetyltransferase gene expression induced by renal ischaemia-reperfusion in rats. $J$ Pharm Pharmacol 2011;63:1037-42.

16. Farag MM, Ahmed GO, Shehata RR, Kazem AH. Thymoquinone improves the kidney and liver changes induced by chronic cyclosporine A treatment an acute renal ischaemia/reperfusion in rats. J Pharm Pharmacol 2015:67:731-9.

17. Mansour MA, Nagi MN, El-Khatib AS, Al-Bekairi AM. Effects of thymoquinone on antioxidant enzyme activities, lipid peroxidation and DT-diaphorase in different tissues of mice: a possible mechanism of action. Cell Biochem Funct 2002;20:143-51.

18. Gökce EC, Kahveci R, Gökce A, Cemil B, Aksoy N, Sargon MF, et al. Neuroprotective effects of thymoquinone against spinal cord ischemiareperfusion injury by attenuation of inflammation, oxidative stress, and apoptosis. J Neurosurg Spine 2016;24:949-59.

19. Gonca E, Kurt C. Cardioprotective effect of Thymoquinone: A constituent of Nigella sativa L., against myocardial ischemia/reperfusion injury and ventricula arrhythmias in anaesthetized rats. Pak J Pharm Sci 2015;28:1267-73.

20. Hammad FT, Lubbad L. The effect of thymoquinone on the renal functions following ischemia-reperfusion injury in the rat. Int J Physiol Pathophysio Pharmacol 2016; 25;8:152-9.

21. Lehtonen L, Põder P. The utility of levosimendan in the treatment of heart failure. Ann Med 2007:39:2-17.

22. Papp Z, Csapó K, Pollesello P, Haikala H, Edes I. Pharmacological mechanisms contributing to the clinical efficacy of levosimendan. Cardiovasc Drug Rev 2005;23:71-98.

23. Papp Z, Edes I, Fruhwald S, De Hert SG, Salmenperä M, Leppikangas H, et al. Levosimendan: molecular mechanisms and clinical implications. Consensus of experts on the mechanisms of action of levosimendan. Int J Cardio 2012;159:82-7.

24. Katrancioglu N, Karahan O, Kilic AT, Altun A, Katrancioglu O, Polat ZA. The antiangiogenic effects of levosimendan in a CAM assay. Microvasc Re 2012;83:263-6.

25. Zinchuk VV. Erythrocyte deformability: physiological aspects. Usp Fiziol Nauk 2001:32:66-78.

26. Kuypers FA. Red cell membrane damage. J Heart Valve Dis 1998;7:387-95

27. Pathak A, Lebrin M, Vaccaro A, Senard JM, Despas F. Pharmacology of levosimendan: inotropic, vasodilatory and cardioprotective effects. J Clin Pharm Ther 2013:38:341-9.

28. Hein M, Zoremba N, Bleilevens $C$, Bruells $C$, Rossaint R, Roehl AB. Levosimendan limits reperfusion injury in a rat middle cerebral artery occlusion (MCAO) model. BMC Neurol 2013;13:106.

29. Yuksel MB, Kavak S, Gecit I, Basel H, Gümrükçüoğlu HA, Demir H, et al. Shortterm levosimendan treatment protects rat testes against oxidative stress. Braz J Med Biol Res 2012;45:716-20.

30. Arslan M, Comu FM, Alkan M, Kiraz HA, Kip G, Özer A, et al. Effect of levosimendan on erythrocyte deformability during myocardial ischaemiareperfusion injury. Bratisl Med J 2015;116: 47-50.

31. Hosseinzadeh $\mathrm{H}$, Parvardeh $\mathrm{S}$, Asl MN, Sadeghnia HR, Ziaee T. Effect of thymoquinone and Nigella sativa seeds oil on lipid peroxidation level during global cerebral ischemia-reperffusion injury in rat hippocampus. Phytomedicine 2007; 14: 621-7.

32. Zaoui $A$, Cherrah $Y$, Alaoui $K$, Mahassine $N$, Amarouch $H$, Hassar $M$. Effects of Nigella sativa fixed oil on blood homeostasis in rat. J Ethnopharmacol 2002;79:23-6

33. Al-Jishi SA, Abuo HB. Effect of Nigella sativa on blood hemostatic function in rats. J Ethnopharmacol 2003;85:7-14 